\title{
IS THERE MONOPSONISTIC DISCRIMINATION AGAINST IMMIGRANTS?
}

\author{
BORIS HIRSCH AND ELKE J. JAHN*
}

\begin{abstract}
The authors investigate immigrants' and natives' labor supply to the firm within an estimation approach based on a dynamic monopsony framework. Applying duration models that account for unobserved worker heterogeneity to a large administrative employer-employee data set for Germany, they find that immigrants supply labor less elastically to firms than do natives. Under monopsonistic wage setting, the estimated elasticity differential predicts a $7.7 \mathrm{log}$ points wage penalty for immigrants thereby accounting for the entire unexplained native-immigrant wage differential of 5.8 to $8.2 \mathrm{log}$ points. When further distinguishing immigrant groups differing in their time spent in the German labor market, their immigration cohort, and their age at entry, the authors find that the observed unexplained wage differential is larger for those groups that show a larger elasticity differential relative to natives. These findings not only suggest that search frictions are a likely cause of employers' more pronounced monopsony power over their immigrant workers but also imply that employers profit from discriminating against immigrants.
\end{abstract}

\footnotetext{
*Boris Hirsch is a Postdoctoral Researcher at the Economics Department at the University of ErlangenNuremberg and Research Fellow at the Institute for the Study of Labor (IZA). ELke J. JAHN is a Senior Researcher at the Institute for Employment Research, Nuremberg, Professor at the Economics Department at the University of Bayreuth, and Research Fellow at the IZA. We thank Marianne Bertrand, Nils Braakmann, Bernt Bratsberg, Herbert Brücker, Bart Cockx, Hartmut Egger, Giovanni Facchini, Katja Görlitz, Tom McKenzie, Michael Neugart, Anne Morrison Piehl, Claus Schnabel, Jan van Ours, Till von Wachter, Thomas Zwick, and three anonymous referees for useful suggestions. We further appreciate comments received from participants of the 10th IZA annual migration meeting in Jerusalem, the Royal Economic Society (RES) 2013 in Royal Holloway, the American Economic Association/Allied Social Science Association (AEA/ASSA) 2013 in San Diego, the European Economic Association \& Econometric Society (ESEM) 2012 in Malaga, the European Society for Population Economics (ESPE) 2012 in Bern, the European Association of Labour Economists (EALE) 2012 in Bonn, the Verein für Socialpolitik (VfS) 2012 in Göttingen, the 3rd TEMPO Conference on International Migration in Nuremberg, and of research seminars at the Rheinisch-Westfälisches Institut für Wirtschaftsforschung (RWI) in Essen, the Technische Universität Darmstadt, and the Bavarian Graduate Program in Economics (BGPE) in Würzburg. Finally, we gratefully acknowledge financial support from the Fritz Thyssen Foundation. A data appendix with additional results, and copies of computer programs used to generate the results presented in the article, are available from the author(s) at elke.jahn@iab.de.
}

KEYWORDS: monopsony, native-immigrant wage differential, discrimination

ILR Review, 68(3), May 2015, pp. 501-528

DOI: 10.1177/0019793915572124. (C) The Author(s) 2015

Journal website: ilr.sagepub.com

Reprints and permissions: sagepub.com/journalsPermissions.nav 
$\mathrm{D}^{\prime}$ uring the early 2000s, a growing number of both theoretical and empirical studies have investigated the prevalence and causes of monopsony in the labor market (Ashenfelter, Farber, and Ransom 2010; Manning 2011). In contrast to the traditional literature on monopsony that saw monopsony power primarily as a consequence of labor markets characterized by demand-side concentration or collusion, this "new" monopsony literature stresses that monopsony power may also be pervasive in labor markets consisting of many competing employers because of search frictions (e.g., Burdett and Mortensen 1998; Manning 2003a), mobility costs (e.g., Brueckner, Thisse, and Zenou 2002; Manning 2003b), or heterogeneous preferences over nonwage job characteristics (e.g., Bhaskar and To 1999; Booth and Coles 2007).

Empirically, whether labor markets should be viewed as monopsonistic rather than competitive or whether the model of perfect competition is a sufficiently good approximation to real-world labor markets, boils down to the question of whether the labor supply curve to the single firm is horizontal or rather imperfectly elastic. A vivid recent empirical literature tries to estimate the firm-level labor supply elasticity. Existing studies either exploit natural experiments (Falch 2010; Staiger, Spetz, and Phibbs 2010) or utilize an estimation approach proposed by Manning (2003a), which builds on equilibrium search theory with wage posting and infers the firm-level labor supply elasticity from the wage elasticity of the firm's separations (Barth and Dale-Olsen 2009; Hirsch, Schank, and Schnabel 2010; Ransom and Oaxaca 2010; Ransom and Sims 2010; Booth and Katic 2011; Falch 2011; Depew and Sørensen 2013; Depew, Norlander, and Sørensen 2013; Webber 2013a, $2013 \mathrm{~b})$. In summary, this literature found that the elasticity is far from infinite, implying that employers possess substantial monopsony power, such that marked deviations from the competitive wage occur. ${ }^{1}$

Another strand of this "new" monopsony literature has tried to assess whether monopsonistic discrimination, the roots of which originate in Robinson's (1933) seminal work applying third-degree factor price discrimination to the labor market, could be a fruitful framework for studying the gender pay gap, as there are several reasons to consider females' labor supply to the firm as less elastic than males'. And, indeed, a growing literature is emerging that finds females' labor supply to the firm is less elastic than males', so that monopsonistic discrimination may explain part of the unexplained gender pay gap in the data (Barth and Dale-Olsen 2009; Hirsch et al. 2010; Ransom and Oaxaca 2010; Webber 2013b).

Up to now, however, no attempt has been made to apply the insights of the new monopsony literature to native-immigrant wage differentials, perhaps because of the immigration literature's focus on questions of wage assimilation and labor market segmentation rather than discrimination

\footnotetext{
${ }^{1}$ One exception is Matsudaira (2014) who cannot reject the case of perfect competition. For a recent overview of this literature, see Manning (2011).
} 
issues, and because of the high data requirements involved. While there is some related evidence of monopsonistic discrimination against undocumented workers for the United States (Hotchkiss and Quispe-Agnoli 2012), no study has investigated native-immigrant differences in firm-level labor supply elasticities. Yet, there are several reasons to presume that such differences exist, and monopsonistic discrimination could contribute to the explanation of native-immigrant wage differentials.

As numerous studies document (see the survey by Dustmann and Glitz 2011), immigrants experience a considerable wage disadvantage compared with natives upon arrival in the host country but manage to close part of the gap during their stay. Following the seminal work by Chiswick (1978), this partial wage assimilation is typically explained in terms of immigrants gaining host country-specific human capital augmenting their productivity. Yet, from a monopsonistic perspective, immigrants' lack of country-specific skills, in particular missing knowledge about labor market institutions and less extensive search networks may result in more severe search frictions for immigrants, thereby providing employers with the possibility of engaging in monopsonistic discrimination against them. It may thus be promising to investigate the case for monopsonistic discrimination against immigrants. This article is intended to fill this gap by estimating labor supply elasticities for native and immigrant males using Manning's (2003a) estimation approach. In particular, we examine whether a monopsonistic perspective may help in understanding the native-immigrant wage differential. The richness and the long time horizon of our administrative linked employeremployee data also enable us to improve on earlier contributions in several ways. First, unlike most previous studies, we have data on job lengths at daily frequency allowing us to use continuous time hazard rate modeling on an inflow sample of job spells thereby accounting for left-truncation and rightcensoring of job durations. Second, we have data on individuals' previous and subsequent labor market status, so that we can explicitly distinguish separations to employment from those to non-employment. Third, we are the first to explicitly control for time-invariant unobserved worker heterogeneity using stratified partial likelihood and conditional logit estimators, further adding to the credibility of our findings.

\section{Theoretical Considerations}

In most countries, significant native-immigrant wage differentials occur, with immigrants' earnings being considerably lower than natives' (e.g., Dustmann and Glitz 2011; for Germany, e.g., Algan, Dustmann, Glitz, and Manning 2010; Dustmann, Glitz, and Vogel 2010). One obvious reason for these differentials can probably be attributed to different endowments in human capital among groups: Immigrants and natives may, for instance, differ in their education levels and their occupations. Furthermore, immigrants may lack country-specific human capital upon arrival in the host country but they may catch up with natives' earnings over time as they 
acquire the missing country-specific skills and gain in productivity. Following Chiswick (1978), a vast literature has investigated whether an assimilation process exists that reduces wage differences between immigrants and natives in the course of time spent in the host country. The general finding of this literature is that large initial differentials tend to decline as immigrants spend time in the host country (e.g., see Dustmann and Glitz 2011).

Apart from productivity differences stemming from missing countryspecific skills, part of the native-immigrant wage differential may also reflect discrimination against immigrants. While employers' prejudices against immigrants may give rise to Beckerian (1971) taste-based discrimination, employers may also possess more monopsony power over immigrant than over native workers, resulting in monopsonistic discrimination against immigrants (Robinson 1933). Indeed, several studies have found nontrivial unexplained wage differentials likely to reflect discrimination against immigrants (e.g., Kee 1995; Nielsen, Rosholm, Smith, and Husted 2004; Elliot and Lindley 2008; Lehmer and Ludsteck 2011).

Empirically, the scope of monopsonistic discrimination as an explanation of immigrant-native wage differentials leads to the question of whether immigrant workers supply labor less elastically to firms than do native workers. Put differently, the question is whether immigrants' labor supply to the firm is less driven by wages than natives'. As the "new" monopsony literature stresses, search frictions, mobility costs, and heterogeneous preferences over nonwage job characteristics are the main forces limiting the elasticity of workers' labor supply to employers. If we think of search frictions-as in the Burdett and Mortensen (1998) model-as a source of employers' monopsony power, immigrants lacking country-specific skills may find it harder to climb the job ladder because they face more severe search frictions and thus end up with lower wages than natives. For instance, immigrants may have a lower job-finding rate because of limited command of the host country's language; limited knowledge on search channels, application routines, and institutional details; or less extensive search networks. Furthermore, considerable workplace segregation of immigrants occurs (Åslund and Skans 2010; Glitz 2014), which is likely to limit their choice of employers. What is more, immigrants have been found to form enclaves (e.g., Cutler, Glaeser, and Vigdor 2008; Granato 2009), which may also limit their regional mobility. All these factors are likely to further impede immigrants' search activities and should therefore provide employers with additional monopsony power over them.

In line with these considerations, Hotchkiss and Quispe-Agnoli (2012) reported that undocumented U.S. workers in Georgia supply labor less elastically to the firm than documented workers, who comprise both natives and legal immigrants, and also showed that this explains part of the observed within-firm wage differential between these two groups. At first sight, one may argue that undocumented workers face similar restraints in their labor supply behavior as immigrants. As undocumented workers can rely only on informal search channels, however, search frictions are arguably of a 
different nature for undocumented workers than for the whole group of immigrants. Therefore, comparing firm-level labor supply elasticities for undocumented and documented workers is unlikely to be informative of the native-immigrant differential that is our point of interest.

That said, there are also some reasons to conjecture as to why immigrants supply labor even more elastically to firms than do natives. If we think of horizontal job differentiation as one source of monopsony power, immigrants may have less pronounced preferences over nonwage job characteristics and may thus be more driven by pecuniary considerations than are natives. For example, immigrants may be less attached to particular firm cultures and institutional details. Furthermore, immigrants typically experience substantial occupational downgrading when entering the host country's labor market (e.g., Chiswick, Lee, and Miller 2005; Constant and Massey 2005) and may try to reduce their occupational mismatch by increased job shopping activities.

It is therefore unclear ex ante whether the elasticity-inhibiting or the elasticity-enhancing factors dominate and whether monopsonistic discrimination against immigrants is thus viable. To assess whether monopsony may explain part of the native-immigrant wage differential, we use an estimation approach proposed by Manning (2003a) to infer the firm-level labor supply elasticity from workers' transition behavior in the labor market separately for immigrants and natives. In a second step, we investigate whether the firm-level labor supply elasticity varies for different subgroups of immigrants. We consider immigrants along three dimensions: 1) their time spent in the host country, 2) their immigration cohort, and 3) their age at entry. Since these immigrants are likely to differ in their search frictions (as detailed below), this not only allows us to further scrutinize the case for monopsonistic discrimination against immigrants but also to shed light on the sources of employers' monopsony power over immigrants.

\section{Econometric Approach}

\section{Estimation of the Firm-Level Labor Supply Elasticity}

The starting point of our econometric approach, which has been pioneered by Manning (2003a: 96-104), is a simple dynamic monopsony model for the labor supply to the firm. Consider a firm paying some wage $w$ at time $t$. We model the change in the labor supply to this firm $L(w)$ as

$$
\dot{L}(w)=R(w)-s(w) L(w),
$$

where $R(w)>0$ denotes the number of recruits arriving at the firm at time $t$ with $R^{\prime}>0$ and $0<s(w)<1$ the separation rate with $s^{\prime}<0$. Accordingly, we assume that the firm can increase its labor supply by increasing its wage and that the labor supply adjusts sluggishly over time. Now consider a steady state with $\dot{L}(w)=0$. Then, we arrive at 


$$
L(w)=R(w) / s(w)
$$

with $L^{\prime}>0 .^{2}$ From Equation (2) we calculate the long-run labor supply elasticity at the level of the firm $\varepsilon_{L W}$ as the difference of the wage elasticity of recruits $\varepsilon_{R W}$ and the wage elasticity of the separation rate $\varepsilon_{S W}$

$$
\varepsilon_{L W}=\varepsilon_{R W}-\varepsilon_{S W}
$$

(see Card and Krueger 1995: 374). Equation (3) further simplifies once we impose more structure on the model. Making use of Burdett and Mortensen's (1998) equilibrium search model with wage posting, which can be thought of as a dynamic model of monopsonistic competition, Manning demonstrated that $\varepsilon_{R W}=-\varepsilon_{S W}$, so that the supply elasticity becomes

$$
\varepsilon_{L W}=-2 \varepsilon_{S W}
$$

Intuitively, this holds because in this model one firm's wage-related hire is another firm's wage-related quit. Equation (4) would allow us to identify the firm-level labor supply elasticity by just estimating the separation rate elasticity and is the basis of the studies by Barth and Dale-Olsen (2009), Ransom and Oaxaca (2010), Ransom and Sims (2010), Falch (2011), as well as Depew and Sørensen (2013).

Enriching the model by incorporating employment and non-employment as distinct labor market states, Manning further showed that the firm-level labor supply elasticity is given by the difference of a weighted average between the recruitment elasticities from employment and non-employment, $\varepsilon_{R W}^{e}$ and $\varepsilon_{R w}^{n}$, and the separation rate elasticities to employment and nonemployment, $\varepsilon_{s W}^{e}$ and $\varepsilon_{s w}^{n}$,

$$
\varepsilon_{L w}=\theta_{R} \varepsilon_{R w}^{e}+\left(1-\theta_{R}\right) \varepsilon_{R w}^{n}-\theta_{s} \varepsilon_{s w}^{e}-\left(1-\theta_{s}\right) \varepsilon_{s w}^{n}
$$

with the weights being given by the share of recruits from employment $\theta_{R}$ and the share of separations to employment $\theta_{s}$, respectively. In a steady state, $\theta \equiv \theta_{R}=\theta_{s}$ holds.

In Burdett and Mortensen's model, workers change employers whenever offered a wage higher than the ongoing one, which is quite restrictive. Allowing for stochastic job-to-job moves and adding more structure to the model, in particular by modeling the separation rate and recruitment functions as iso-elastic in wages, Manning demonstrated that the long-run elasticity of the labor supply to the firm is given by

$$
\varepsilon_{L w}=-(1+\theta) \varepsilon_{s w}^{e}-(1-\theta) \varepsilon_{s w}^{n}-\varepsilon_{\theta w},
$$

where $\varepsilon_{\theta w}$ denotes the wage elasticity of the share of recruits hired from employment and, together with $\theta$, informs us on the recruitment function

\footnotetext{
${ }^{2}$ Note that perfect competition is nested as the case with $L^{\prime} \rightarrow \infty$ due to $s^{\prime} \rightarrow-\infty$ and $R^{\prime} \rightarrow \infty$ at the competitive market wage that equalizes labor supply and demand at the market level.
} 
of the firm. ${ }^{3}$ While this approach is clearly more general than just relying on Equation (4), it is much more demanding in terms of data requirements and has been adopted by only Hirsch et al. (2010) and Booth and Katic (2011). To determine the supply elasticity as given in Equation (6), one has to estimate 1) the separation rate elasticity to employment $\left.\varepsilon_{s w}^{e}, 2\right)$ the separation rate elasticity to non-employment $\varepsilon_{s w}^{n}$, 3) the wage elasticity of the share of hires from employment $\varepsilon_{\theta_{w}}$ and 4) the share of hires from employment $\theta$.

\section{Empirical Specification}

Following Manning's approach, we estimate the separation rate elasticities $\varepsilon_{S W}^{e}$ and $\varepsilon_{s W}^{n}$ from two hazard rate models for the instantaneous separation rates to employment and non-employment. We model the respective separation rate of job spell $i$ belonging to worker $m$ as

$$
s_{i}^{\rho}\left(t \mid \mathbf{x}_{i}^{\rho}(t)\right)=s_{m(i) 0}^{\rho}(t) \exp \left(\mathbf{x}_{i}^{\rho}(t)^{\prime} \boldsymbol{\beta}^{\rho}\right)
$$

with route $\rho=e, n$, baseline hazard $s_{m(i) 0}(t)$, a vector of time-varying covariates $\mathbf{x}_{i}^{\rho}(t)$, and a vector of coefficients $\boldsymbol{\beta}^{\rho}$, where $t$ corresponds to the time since the start of the job spell, that is, job tenure. Note that the baseline hazard $s_{m(i) 0}^{\rho}(t)$ is some arbitrary worker-specific function of job tenure thereby encompassing time-invariant unobserved heterogeneity at the level of worker $m(i)$. Including the log wage as covariate results in an iso-elastic separation rate as required by Manning's approach, and its coefficient gives the respective separation rate elasticity $\varepsilon_{s w}^{\rho}{ }^{4}$

We should make clear that controlling for unobserved worker heterogeneity in the separation equations is indispensable for our investigation as we have little information on natives' and particularly immigrants' socioeconomic backgrounds, though these are likely to differ considerably. As a case in point, our data (for the details, see the data section below) do not contain information on immigrants' pre-migration labor market performance or their motivation. We do not know either whether immigrants experienced occupational downgrading when entering the German labor market. All these factors may obviously affect immigrants' wages and outside options and cause them to differ substantially from natives'. However, they are only partly reflected in, though certainly correlated with, immigrants' observed characteristics. By eliminating between-worker variation we would thus eliminate the bias in elasticities stemming from good workers receiving both higher wages and more outside options.

\footnotetext{
${ }^{3}$ Note that the simpler approach as given by Equation (4) is nested as $\varepsilon_{s w}^{n}, \varepsilon_{\theta w} \rightarrow 0$ and $\theta \rightarrow 1$.

${ }^{4}$ Assuming conditional independence of the separation probabilities to employment and non-employment, Manning showed that they can be estimated separately by two independent hazard rate models. When estimating the separation rate to non-employment, all job spells are used. Yet, when estimating the separation rate to employment, only those job spells that do not end with a transition to non-employment are considered. Note that since we will model the route-specific hazard rates as stratified Cox models that control for unobserved time-invariant worker heterogeneity in the following, separation probabilities just have to be independent conditionally on observed covariates and unobserved worker heterogeneity.
} 
To do so, we make use of stratified Cox models in which the baseline hazard is assumed to be worker-specific and thus captures time-invariant unobserved worker heterogeneity. It is important to stress that by allowing for worker-specific baseline hazards, the proportionality assumption inherent to the class of hazard rate models defined by Equation (7) needs to hold only for job spells belonging to the same worker but may very well be violated across workers without invalidating identification (see Kalbfleisch and Prentice 2002: 118-19). As a consequence, our estimations relying on stratified Cox models do not suffer from the widely raised criticism against proportional hazard models.

To estimate stratified Cox models, we adopt the stratified partial likelihood estimator that allows us to sweep out the worker-specific baseline hazard without the need of identifying it and thus to estimate the covariates' coefficients while controlling for unobserved worker heterogeneity in a similarly convenient way as with the within estimator in linear fixed-effects models (see Ridder and Tunali 1999). ${ }^{5}$ The stratified partial likelihood estimator does so by resting the identification of $\boldsymbol{\beta}^{\rho}$ on within-variation at the worker level. Hence, it requires multiple job spells per worker and thus, long and rich enough data. The use of stratified Cox models therefore allows us to go beyond the existing literature on monopsonistic (gender) discrimination, such as Barth and Dale-Olsen (2009), Hirsch et al. (2010), Ransom and Oaxaca (2010), and Webber (2013b), by controlling for unobserved worker heterogeneity that may be correlated with included covariates. It also considerably mitigates possible concerns on the endogeneity of workers' wages in the separation equations.

That said, estimating stratified Cox models forces us to control for job tenure. As already stated, the worker-specific baseline hazard $s_{m(i) 0}^{\rho}(t)$ in Equation (7) drops out of the partial likelihood function and does so without being constrained to be constant over job tenure $t$. By estimating stratified Cox models we thus not only control for unobserved worker heterogeneity but also for job tenure. On the one hand, as argued by Manning (2003a: 103), in models of dynamic monopsony à la Burdett and Mortensen (1998), firms pay higher wages in order to reduce separations and to increase tenure. Controlling for tenure would fail to attribute this indirect effect on the separation rate to wages. In other words, job tenure would be a "bad control variable," in Angrist and Pischke's (2009: 64-68) terminology, in that it is itself partly determined by wages. On the other hand, Manning also acknowledged that the positive relationship between wages and tenure may be spurious under seniority wage scales. In this case, controlling for tenure may give better estimates. Since ample evidence suggests that seniority wage schedules are widespread in the German labor market (see, e.g., Zwick 2011, 2012), we think controlling for tenure is appropriate in our application, in particular as this allows us to deal with unobserved worker heterogeneity, which is a serious issue.

${ }^{5}$ Stratified Cox models are estimated with Stata's stcox routine using the strata option. 
To estimate the wage elasticity of the share of recruits hired from employment $\varepsilon_{\theta w}$, we model the probability that a worker is hired from employment (as opposed to non-employment) as a logit model

$$
\operatorname{Pr}\left[y_{i}=1 \mid \mathbf{x}_{i}, \mathrm{v}_{m(i)}\right]=\Lambda\left(\mathbf{x}_{i}^{\prime} \boldsymbol{\beta}+\mathrm{v}_{m(i)}\right),
$$

where notation follows the same rules as before, $y_{i}$ is an indicator variable for a hire from employment, $v_{m(i)}$ is a worker fixed effect, and $\Lambda$ denotes the cumulative distribution function of the standard-logistic distribution. To remove unobserved worker heterogeneity correlated with observed characteristics, we use the conditional logit (or fixed-effects logit) estimator (see, e.g., Cameron and Trivedi 2005). Intuitively, this estimator controls for worker fixed effects by conditioning on those workers who are hired from employment at one point of time and from non-employment at another and discarding those always hired from the same labor market status. Identification of $\boldsymbol{\beta}$ thus relies on those workers for whom $y_{i}$ changes over time, that is, workers with at least two job spells and different previous labor market status. As can be readily shown, when including the log wage as a covariate in Equation (8), its coefficient gives the wage elasticity of the share of recruits hired from employment $\varepsilon_{\theta w}$ divided by $1-\theta$. So multiplying the coefficient by $1-\theta$ yields the estimate of the wage elasticity we are aiming for.

The last step to reach an estimate of the firm-level labor supply elasticity is to estimate the share of hires from employment $\theta$. We do so by simply taking the observed average from the data. Then using Equation (6) yields an estimate for the labor supply elasticity with standard errors for the estimated elasticity being provided by the bootstrap.

\section{Economic Interpretation of the Estimates}

To assess the economic relevance of the estimated native-immigrant firmlevel supply elasticity differential, we use the fact that in a simple (dynamic) model of monopsony, firms maximize profits by setting a worker's wage to

$$
w=\frac{\varepsilon_{L w}}{1+\varepsilon_{L w}} \phi,
$$

where $\phi$ denotes the worker's marginal revenue product. ${ }^{6}$ Consider now immigrants and natives with the same marginal revenue product $\phi$ but different elasticities $\varepsilon_{L W}^{I}$ and $\varepsilon_{L W}^{N}$ on average, where the superscripts $I$ and $N$ refer to immigrant and native workers, respectively. Assuming the same average productivity across immigrants and natives is plausible as our stratified Cox and conditional logit estimations have controlled for both standard human

\footnotetext{
${ }^{6}$ To derive Equation (9) in a dynamic monopsony model, we would have to assume that firms maximize steady-state profits and discount future profits at a negligible rate, as is the case in the Burdett and Mortensen (1998) model. Note that Equation (9) can readily be rearranged to display $(\phi-w) / w=1 /$ $\varepsilon_{L W}$, which is the analog to the well-known Lerner index from the industrial organization literature.
} 
capital variables and unobserved worker heterogeneity. Then the immigrant-native wage differential following from Equation (9) is

$$
\ln w^{I}-\ln w^{N} \approx \frac{w^{I}-w^{N}}{w^{N}}=\frac{\varepsilon_{L w}^{I}-\varepsilon_{L w}^{N}}{\varepsilon_{L w}^{N}\left(\varepsilon_{L w}^{I}+1\right)},
$$

and Equation (10) provides us with an estimate of the immigrant-native wage differential arising under monopsonistic discrimination, that is, in a situation where firms exploit their range of monopsony power over immigrant and native workers (e.g., by different initial job assignments and/or different access to subsequent promotions).

\section{Data}

To put this approach into practice, we need detailed data on job lengths, preceding and subsequent jobs, and periods of non-employment, as well as data on workers and employers over a long period of time. Otherwise, correcting for unobserved worker heterogeneity by means of stratified Cox and conditional logit models and multiple-spell data could not be done convincingly. For our purpose, we combine two administrative data sets for the period 1985 to 2008: the Sample of Integrated Labour Market Biographies (SIAB) and the Establishment History Panel (BHP) provided by the Institute for Employment Research (IAB).

The data on job lengths (on a daily basis), transitions, wages, and worker characteristics come from the SIAB. The SIAB comprises a $2 \%$ random sample of all wage and salary employees registered with the German social security system during the period 1975 to 2008 , in which sampling is at the level of the worker. About $80 \%$ of all people employed in Germany are covered by the system (for details, see Dorner, Heining, Jacobebbinghaus, and Seth 2010). Since the information contained is used to calculate social security contributions, the data set is highly reliable and especially useful for analyses taking wages and job durations into account.

Information on employers comes from the BHP, which again consists of data from the German social insurances that are this time aggregated at the plant level as of the 30th of June of a given year (for details, see Spengler 2008). It not only contains information on plants' workforce composition and size but also on downsizing and plant closures. ${ }^{7}$ This information is particularly important as we aim at identifying the impact of wages on individual workers' separation decisions and cannot distinguish voluntary quits from involuntary dismissals in our data. While plant controls are intended to mitigate this problem to some extent, without correcting for downsizing and closing plants, part of the measured effect of wages on separations and hirings may be

\footnotetext{
${ }^{7}$ We classify as downsizing plants those plants that reduce employment by more than $25 \%$ in the current or consecutive year. As closing plants we take those plants that drop out of the BHP because they stop having any employees covered by social security.
} 
demand-driven rather than a supply-side response and may for this reason not allow us to infer the firm-level labor supply elasticities from separation rate elasticities. As a case in point, if being paid a low wage reflects low productivity of an employer and low-productivity employers are more likely to be driven out of the market, this may result in a negative correlation between separations and wages that is not driven by workers' supply behavior. To alleviate this problem, we will exclude job spells in downsizing as well as closing plants.

Our data allow us to identify immigrants only on the basis of citizenship. Because of the jus sanguinis tradition of the German law, naturalization rates are traditionally very low, so that second-generation immigrants are still likely to possess foreign citizenship. To mitigate possible effects of naturalization, we follow Brücker and Jahn (2011) and classify all individuals as immigrants who are reported as foreign citizens in their first observation available. Another important immigrant group, which possesses German citizenship, consists of so-called ethnic Germans or (Spät-)Aussiedler (for details on ethnic German immigrants, see Hirsch, Jahn, Toomet, and Hochfellner 2014). Since ethnic Germans' labor market performance in general resembles that of other immigrants (see Glitz 2012; Hirsch et al. 2014), we again follow Brücker and Jahn (2011) and classify them as immigrants. ${ }^{8}$

Our data contain observations for East German workers only from 1992 onward. Restricting our analysis to the post-unification period would markedly reduce our period of observation and thus the scope of our investigation. It would also add only a few observations for immigrants as the wage and salary immigrant population in East Germany is small. We will thus focus our analysis throughout on individuals working in West Germany (excluding Berlin) during the period 1985 to 2008 and further restrict it to males aged 18 to 55 years.

The merged data set allows us to build up an inflow sample of job spells starting between 1985 and 2008 taking into account workers' previous labor market status, the job length, and-provided the job ended during our period of observation-workers' subsequent labor market status. ${ }^{9}$ We follow our theoretical model and distinguish two labor market states: employment and non-employment. Consequently, a job may end with a transition to employment, which refers to a new job with another employer (i.e., a plant with a different plant identifier), or with a transition to non-employment, which refers to a subsequent spell in registered unemployment or no spell in the data at all. ${ }^{10}$ The latter either implies that the individual has changed

\footnotetext{
${ }^{8}$ In our data set, we are able to identify the vast majority of ethnic German immigrants (though these have German citizenship) because of previous participation in language courses and recipience of integration subsidies recorded in the data. For details, see Brücker and Jahn (2011).

${ }^{9}$ Note that plant-level variables, which are only recorded at the 30th of June of a year, are merged to all spells that happen in the same calendar year and are treated as time-varying over the duration of any spell. (This is possible because employers have to provide information on ongoing employment spells at least once a year or if changes take place.)

${ }^{10}$ Note that separations to non-employment are ignored if the employee is recalled by the same plant within three months. Similarly, in classifying job-to-job moves we allow a gap of up to three months between two subsequent employment spells with different plants if no other labor market status, like registered unemployment, is recorded in the data.
} 
to non-employment without receiving unemployment benefits or that he has become, for instance, a self-employed worker not included in the data set. While our data do not enable us to disaggregate this category of unknown destination, information from other German data sets suggests that the vast majority of employees in this category have indeed moved to non-employment. ${ }^{11}$

Whereas information on job spells and daily gross wages included in the data are highly reliable, the data include no detailed information on the number of hours worked. Also, wages are top-coded at the social security contribution ceiling, which affects $10.7 \%$ of our observations. To deal with the first drawback, we restrict our analysis to full-time workers. To cope with the second, we impute wages above the ceiling using a heteroskedastic single imputation approach developed by Büttner and Rässler (2008) for this data set. ${ }^{12}$ Information on workers' education is provided by employers; consequently, this information is missing for $5.7 \%$ of all observations. To alleviate this problem, we impute the missing information on education by employing a procedure proposed by Fitzenberger, Osikominu, and Völter (2006) that allows inconsistent education information to be corrected. After applying this imputation procedure, only about $1.3 \%$ of the job spells are dropped due to missing or inconsistent information on education.

\section{Descriptive Evidence}

Our final sample consists of 712,466 job spells belonging to 256,373 native workers and 148,013 spells belonging to 57,406 immigrant workers. Note that according to these numbers, $18.3 \%$ of the workers in our sample are immigrants. As in 2011, the share of individuals in Germany with a migration background amounted to $19.5 \%$ (Statistisches Bundesamt 2012), hence our classification of immigrant workers seems to work reasonably well. For descriptive statistics on key variables, see Appendix Table A.1. As can be seen from Table 1, which gives an overview of our sample of job spells and the transitions between employment and non-employment, the majority of workers $(62.2 \%$ of natives and $58.7 \%$ of immigrants) have at least two job spells in the data, and out of these, roughly two-thirds have changing previous labor market states. This enables us to implement our estimation strategy relying on stratified Cox and conditional logit models controlling for unobserved time-invariant worker heterogeneity.

Table 1 also makes clear that natives and immigrants show different transition behavior both with respect to hirings and to separations: First, natives

\footnotetext{
${ }^{11}$ See, for example, Bartelheimer and Wieck (2005) for a transition matrix between employment and non-employment based on the German Socio-Economic Panel that allows stratification of the "unknown" category into detailed categories.

${ }^{12}$ Note that including imputed wages as covariates in the stratified Cox and conditional logit models may introduce some bias in estimated wage elasticities. As a check of robustness, we repeated all estimations excluding job spells with top-coded wages, which gave very similar results.
} 
Table 1. Job Spells and Transitions

\begin{tabular}{lcccc}
\hline Group & \multicolumn{2}{c}{ Natives } & \multicolumn{2}{c}{ Immigrants } \\
\hline Job spells & 712,466 & \multicolumn{2}{c}{148,013} & \\
Workers & 256,373 & \multicolumn{2}{c}{57,406} & \\
Plants & 296,474 & & 79,632 & \\
& & & 2.6 & \\
Average job spells per worker & 2.8 & & 58.7 & \\
Percentage of workers with more than one job spell & 62.2 & & 61.5 & \\
Percentage of multiple-jobs workers with both & 64.6 & & & \\
$\quad$ employment and non-employment as previous labor & & & & \\
$\quad$ market status & & & & \\
& & & & \\
Hires from employment & 335,570 & $(47.1)$ & 51,158 & $(34.6)$ \\
Hires from non-employment & 376,896 & $(52.9)$ & 96,855 & $(65.4)$ \\
& & & & \\
Separations to employment & 282,722 & $(39.7)$ & 45,739 & $(30.9)$ \\
Separations to non-employment & 323,139 & $(45.4)$ & 84,441 & $(57.0)$ \\
Right-censored job spells & 106,605 & $(15.0)$ & 17,833 & $(12.0)$ \\
\hline
\end{tabular}

Notes: The data sets used are the SIAB and BHP, 1985-2008. Percentages are shown in parentheses.

are less often hired from non-employment, with a share of hires from nonemployment of $52.9 \%$ compared with a share of $65.4 \%$ for immigrants. ${ }^{13}$ Since the share of hires from non-employment can serve as a simple measure of search frictions in the labor market (see Manning 2003a: 44-49), our findings are a first indication that immigrants face more severe search frictions. Intuitively, the share reflects the difficulties of climbing the job ladder by wage-increasing job-shopping activities. Second, immigrants are relatively more likely to exit existing jobs to non-employment than to employment (with separation rates to non-employment and employment of $57.0 \%$ and $30.9 \%$, respectively) as compared to natives (who have rates of $45.4 \%$ and $39.7 \%$, respectively). Again, this may reflect differences in search frictions as separations to employment are more likely to reflect voluntary job-to-job moves as a means of achieving better-paying jobs and reducing job mismatch.

Turning to wages, we find a large, average, raw native-immigrant wage differential of $20.4 \mathrm{log}$ points (see Appendix Table A.1). In a next step, we run some standard extended Mincerian wage regressions controlling for several worker, job, and plant characteristics to arrive at an estimate of the unexplained wage differential in our sample. In these estimations, we

\footnotetext{
${ }^{13}$ As detailed above, our estimation approach assumes steady-state conditions with the share of hires from and the share of separations to employment being equal, i.e., $\theta \equiv \theta_{R}=\theta_{s}$. As can be seen from Table 1 , our data are in line with this assumption: The share of hires from employment is $47.1 \%$ for natives and $34.6 \%$ for immigrants, and the share of separations to employment (i.e., the share of non-censored jobs with a subsequent transition to employment) is $46.7 \%$ and $35.1 \%$, respectively. While these numbers suggest that our steady-state approach may be appropriate, Webber (2013a) presented evidence that suggests our estimates of the firm-level labor supply elasticity would be biased downward if the steady-state assumption were invalid, though the bias appears to be modest in size.
} 
include 6 age and 2 education dummies as socioeconomic variables. ${ }^{14} \mathrm{Job}$ controls are 11 occupation and 7 job tenure dummies. ${ }^{15}$ As plant controls, we further include 4 plant-size dummies; the shares of immigrant, part-time, high-skilled, low-skilled, and female workers in the plant's workforce; the median age of the plant's workers; and 24 sector dummies. All estimations also include year dummies, dummies for the size of the region where the firm is located (i.e., rural, urban, or metropolitan), and the unemployment rate at the municipality level.

Running these regressions, the results of which are shown in Table 2, yields an average unexplained native-immigrant wage differential (i.e., coefficient of the immigrant dummy) of 5.8 to $15.0 \mathrm{log}$ points depending on specification. Notably, the gap drops from 15.0 to $8.2 \log$ points when adding occupation and tenure controls, so that part of the pay gap is likely to reflect that immigrants work in low-tenure jobs and low-paying occupations (in line with the literature, e.g., Eckstein and Weiss 2004; Constant and Massey 2005). When also controlling for plant characteristics, the gap is reduced further to $5.8 \mathrm{log}$ points, which indicates that immigrants are employed in low-paying plants (see, e.g., Pendakur and Woodcock 2010; Barth, Bratsberg, and Raaum 2012). Overall, these findings are consistent with our theoretical considerations suggesting that immigrants are constrained to worse occupations because they lack mobility or have less successful job searches. In the following analysis, we will consider the range spanned by these latter two figures as a benchmark of the unexplained native-immigrant wage gap. ${ }^{16}$

\section{Results}

To estimate labor supply elasticities at the firm level for both immigrants and natives, thereby assessing whether monopsonistic discrimination may provide an explanation of the native-immigrant wage differential in our sample, we use the econometric approach discussed above. We estimate stratified Cox models for the instantaneous separation rates to employment and non-employment and conditional logit models for the probability that a worker is hired from employment separately for natives and immigrants. Including the job's log wage in these estimations we arrive at estimates of the separation rate elasticities to employment and non-employment as well

\footnotetext{
${ }^{14}$ We distinguish three different skill levels: Low-skilled individuals are those with neither vocational training nor academic education, medium-skilled are those with vocational training, and high-skilled are those with an academic education.

${ }^{15}$ Occupation groups are 1) agricultural occupations, 2) simple and 3) qualified manual occupations, 4) engineers, 5) technicians, 6) simple and 7) qualified service occupations, 8) semi-professionals, 9) professionals, 10) simple and 11) qualified clerical occupations, and 12) managers.

${ }^{16}$ Note that including much more detailed region and occupation controls does not change the immigrant pay gap. For example, adding 326 region fixed effects; 329 (three-digit) occupation dummies; and interactions of the education, age, and tenure dummies with a linear and quadratic time trend reduces the coefficient of the immigrant dummy just marginally (viz. to -0.052 instead of -0.058 in model 3). Yet, we do not present these models for the sake of consistency since we cannot include such a vast number of control variables in the hazard rate and logit models for computational reasons.
} 
Table 2. Wage Regressions

\begin{tabular}{|c|c|c|c|c|c|c|}
\hline \multirow{2}{*}{$\frac{\text { Variable }}{\text { Immigrant (dummy) }}$} & \multicolumn{2}{|c|}{ Model 1} & \multicolumn{2}{|c|}{ Model 2} & \multicolumn{2}{|c|}{ Model 3} \\
\hline & -0.150 & $(0.002)$ & -0.082 & $(0.002)$ & -0.058 & $(0.001)$ \\
\hline Medium-skilled (dummy) & 0.162 & $(0.002)$ & 0.119 & $(0.002)$ & 0.087 & $(0.001)$ \\
\hline High-skilled (dummy) & 0.569 & $(0.003)$ & 0.341 & $(0.003)$ & 0.258 & $(0.003)$ \\
\hline Age $18-25$ years (dummy) & -0.168 & $(0.001)$ & -0.105 & $(0.001)$ & -0.092 & $(0.001)$ \\
\hline Age $31-35$ years (dummy) & 0.112 & $(0.001)$ & 0.079 & $(0.001)$ & 0.073 & $(0.001)$ \\
\hline Age $36-40$ years (dummy) & 0.171 & $(0.001)$ & 0.124 & $(0.001)$ & 0.113 & $(0.001)$ \\
\hline Age $40-45$ years (dummy) & 0.193 & $(0.002)$ & 0.144 & $(0.001)$ & 0.131 & $(0.001)$ \\
\hline Age $46-50$ years (dummy) & 0.187 & $(0.002)$ & 0.146 & $(0.002)$ & 0.129 & $(0.002)$ \\
\hline Age $51-55$ years (dummy) & 0.157 & $(0.003)$ & 0.132 & $(0.002)$ & 0.114 & $(0.002)$ \\
\hline Tenure $1-4$ years (dummy) & & & 0.170 & $(0.001)$ & 0.116 & $(0.001)$ \\
\hline Tenure 5-9 years (dummy) & & & 0.254 & $(0.001)$ & 0.168 & $(0.001)$ \\
\hline Tenure $10-14$ years (dummy) & & & 0.303 & $(0.002)$ & 0.198 & $(0.001)$ \\
\hline Tenure 15-19 years (dummy) & & & 0.348 & $(0.003)$ & 0.222 & $(0.002)$ \\
\hline Tenure $\geq 20$ years (dummy) & & & 0.404 & $(0.005)$ & 0.254 & $(0.004)$ \\
\hline Plant size $11-50$ (dummy) & & & & & 0.074 & $(0.001)$ \\
\hline Plant size 51-200 (dummy) & & & & & 0.105 & $(0.002)$ \\
\hline Plant size $201-1,000$ (dummy) & & & & & 0.163 & $(0.002)$ \\
\hline Plant size $>1,000$ (dummy) & & & & & 0.210 & $(0.002)$ \\
\hline Share of immigrant workers & & & & & -0.094 & $(0.004)$ \\
\hline Share of female workers & & & & & -0.126 & $(0.003)$ \\
\hline Share of high-skilled workers & & & & & 0.280 & $(0.004)$ \\
\hline Share of low-skilled workers & & & & & -0.122 & $(0.002)$ \\
\hline Share of part-time workers & & & & & -0.048 & $(0.004)$ \\
\hline Median age of workers at the plant & & & & & 0.005 & $(0.000)$ \\
\hline One-digit occupation & & & \multicolumn{2}{|c|}{$\checkmark$} & \multicolumn{2}{|c|}{$\checkmark$} \\
\hline Two-digit industry & & & & & \multicolumn{2}{|c|}{$\checkmark$} \\
\hline Observations & \multicolumn{2}{|c|}{$2,928,280$} & \multicolumn{2}{|c|}{$2,928,280$} & 2,92 & 280 \\
\hline$R^{2}$ & \multicolumn{2}{|c|}{0.280} & \multicolumn{2}{|c|}{0.422} & \multicolumn{2}{|c|}{0.526} \\
\hline
\end{tabular}

Notes: The data sets used are the SIAB and BHP, 1985-2008. The regressand is the daily gross log wage. Standard errors clustered at the individual level are given in parentheses. All models include year dummies, two dummies indicating the size of the regional labor market, and the unemployment rate at the municipality level. In addition, models 2 and 3 contain 11 occupation dummies and model 3 also 24 sector dummies.

as the wage elasticity of the share of hires from employment. We can then plug these estimates into Equation (6) to arrive at an estimate of the firmlevel labor supply elasticity and use Equation (10) to calculate the implied native-immigrant pay gap under monopsonistic wage setting.

With the exception of the job tenure dummies (tenure is controlled for by the non-parametric worker-specific baseline hazard in the stratified Cox models), we include in all estimations the same covariates (listed in the notes to Table 3 ) as in the wage regressions and treat them as time-varying. In particular, we include 11 occupation dummies. Controlling for occupations is important because occupational downgrading of immigrants is likely to be negatively correlated with wages but positively correlated with the separation probability. Omitting occupation controls in the estimations would 
therefore inflate the wage effect in the separation equations and thus bias the estimated separation elasticity upward (in absolute value). Furthermore, including plant characteristics such as the share of immigrant or low-skilled workers, plant size, and industry is important because of possible workplace segregation of immigrants. Finally, we include year dummies and the unemployment rate at the municipality level as controls capturing the labor market state. In our estimations, we account for unobserved worker heterogeneity by eliminating between-worker variation in separation rates and wages. Hence, a larger part of the identifying variation for the separation rate elasticities stems from macro shocks faced by individuals over time, with all workers receiving higher wages and more outside options during good times. Our macro controls account for this.

As can be seen from Table 3, which reports the estimated parameters required to arrive at the firm-level labor supply elasticity using Equation (6), the separation rate elasticities to employment and non-employment as well as the wage elasticity of the share of hires from employment are lower (in absolute value) for immigrants than for natives. As a consequence, the resulting firm-level labor supply elasticity is significantly smaller $(p=0.016)$ for immigrants, the estimates being 1.136 for immigrants and 1.360 for natives. Bear in mind that our estimation approach to the separation rate elasticities assumes that wages are conditionally exogenous with respect to job tenure to yield unbiased estimates. Yet, this assumption does not hold if high-ability (and thus high-wage) workers self-select into stable jobs (Altonji and Williams 2005) or if workers' wages respond to their job opportunities (Pencavel 1972). Both of these points, and in particular the former one, should pose less a problem when controlling for permanent unobserved worker heterogeneity. However, wages may still respond to changes in individuals' job opportunities. While we cannot rule out that this may cause some bias in our estimations, we think this problem is less compelling after we drop high-wage workers, that is, high-skilled workers or workers in highskilled occupations who may renegotiate wages with their employers. As a check of robustness, we therefore dropped these groups of workers and redid our analysis. As Appendix Table A.2 makes clear, our insights are unaltered when 1) dropping high-skilled individuals or 2) restricting to workers in low-skilled occupations (i.e., agricultural as well as simple manual, service, and clerical occupations). We therefore think it implausible that our findings are attributable to potential endogeneity of the wage.

To obtain an impression of what drives the native-immigrant difference in the firm-level labor supply elasticity, we next decompose the difference into its components. Table 4, which presents this decomposition, makes clear that all components matter quantitatively. Together, immigrants' less wage-elastic separations to employment and non-employment, meaning their separation decisions are less driven by wages, account for $79 \%$ of the difference. Another $67 \%$ stem from the different composition of plants' inflows of immigrant and native recruits, with immigrants more likely to be hired from non-employment and thus less likely than natives to be 
Table 3. Estimated Firm-Level Labor Supply Elasticities and the Implied Immigrant-Native Pay Gap

\begin{tabular}{|c|c|c|c|c|}
\hline \multirow{3}{*}{$\frac{\text { Parameter }}{\text { Separation rate elasticity to employment }\left(\hat{\varepsilon}_{s w}^{e}\right)}$} & \multicolumn{4}{|c|}{$\begin{array}{l}\text { Stratified Cox and conditional logit models } \\
\text { controlling for unobserved worker heterogeneity }\end{array}$} \\
\hline & \multicolumn{2}{|c|}{ Natives } & \multicolumn{2}{|c|}{ Immigrants } \\
\hline & -1.039 & $(0.017)$ & -0.956 & $(0.041)$ \\
\hline Separation rate elasticity to non-employment $\left(\hat{\varepsilon}_{s w}^{n}\right)$ & -0.793 & $(0.012)$ & -0.686 & $(0.024)$ \\
\hline $\begin{array}{l}\text { Wage elasticity of the share of recruits hired from } \\
\text { employment }(\varepsilon \theta w /(1-\theta))\end{array}$ & 1.110 & $(0.014)$ & 0.916 & $(0.032)$ \\
\hline Share of hires from employment $(\hat{\theta})$ & 0.471 & & 0.346 & \\
\hline Firm-level labor supply elasticity $\left(\hat{\varepsilon}_{L w}\right)$ & 1.360 & $(0.035)$ & 1.136 & $(0.084)$ \\
\hline $\begin{array}{l}\text { Test for equality of firm-level labor supply elasticities } \\
\text { between immigrants and natives }\end{array}$ & \multicolumn{4}{|c|}{$p=0.016$} \\
\hline Implied immigrant-native pay gap $\left(\overline{\ln w^{I}-\ln w^{N}}\right)$ & \multicolumn{4}{|c|}{-0.077} \\
\hline
\end{tabular}

Notes: The data sets used are the SIAB and BHP, 1985-2008. Standard errors clustered at the individual level are shown in parentheses. The standard errors for the firm-level labor supply elasticities are cluster bootstrapped with 400 replications. Covariates included in the estimations are 2 education, 6 age, 4 plant size, 11 occupation, 24 sector, 23 year, and 2 dummies for the size of the region where the plant is located; the shares of part-time, high-skilled, low-skilled, female, and immigrant workers in the plant's workforce; the median age of its workforce; and the unemployment rate at the municipality level. Detailed results are available on request.

successful in an on-the-job search. In contrast, the lower wage elasticity of the share of recruits hired from employment for immigrants increases the difference by $46 \%$. This value reflects that paying a higher wage raises the share of hires from employment to a greater extent for natives than for immigrants. Thus, by increasing wages, employers find it relatively easier to poach natives than immigrants. And to woo a certain number of immigrants requires a higher wage than poaching the same number of natives.

Applying Equation (10) to our results, we find that the estimated elasticity differential implies a ceteris paribus earnings disadvantage for immigrants of $7.7 \log$ points. Note that this number is very close to the unexplained immigrant-native wage differential in our sample amounting to 5.8 to 8.2 $\log$ points depending on the set of covariates included (see models 2 and 3 in Table 2). Our reading of this result is that the entire unexplained differential can be accounted for by monopsonistic discrimination with the less elastic group of immigrant workers receiving lower wages than comparable native workers. ${ }^{17}$

\footnotetext{
${ }^{17}$ In further specifications (shown in Appendix Tables A.3 and A.4), we checked which elements of our econometric approach are crucial to our findings. 1) When not controlling for unobserved worker heterogeneity by using standard Cox and logit rather than stratified Cox and conditional logit models immigrants' estimated firm-level labor supply elasticity is even significantly larger than natives'. The bias caused by unobserved worker heterogeneity would thus mislead us to expect a wage premium for immigrants of $4.8 \log$ points. 2) Not distinguishing employment and non-employment as distinct labor market states by lumping together all separations and estimating the supply elasticity by Equation (4) reduces the difference in elasticities between natives and immigrants by a third, though the difference remains statistically and economically significant. 3) Not controlling for occupations does not change our results, whereas 4) not controlling for plant characteristics halves the difference in elasticities, which also becomes statistically insignificant.
} 
Table 4. Decomposition of the Native-Immigrant Difference in the Firm-Level Labor Supply Elasticity

\begin{tabular}{lcc}
\hline & $\begin{array}{c}\text { Natives' estimated } \\
\text { firm-level } \\
\text { labor supply elasticity }\end{array}$ & $\begin{array}{c}\text { Change in \% of the native- } \\
\text { immigrant difference in the } \\
\text { labor supply elasticity (\%) }\end{array}$ \\
\hline $\begin{array}{l}\text { Nomponent } \\
\text {. . when using immigrants' estimated separation } \\
\text { rate elasticity to employment }\end{array}$ & 1.360 & -54.5 \\
$\begin{array}{l}\text {. when additionally using immigrants' estimated } \\
\text { separation rate elasticity to non-employment } \\
\text {. when additionally using immigrants' estimated } \\
\text { wage elasticity of the share of recruits hired from } \\
\text { employment }\end{array}$ & 1.239 & -25.4 \\
$\begin{array}{l}\text {. . when additionally using immigrants' estimated } \\
\text { share of hires from employment (= immigrants' } \\
\text { estimated supply elasticity) }\end{array}$ & 1.182 & +46.0 \\
\hline
\end{tabular}

Notes: The data sets used are the SIAB and BHP, 1985-2008. The decomposition is based on the estimates from Table 3.

To further scrutinize the robustness of our findings and to shed some light on the likely sources of employers' more pronounced monopsony power over immigrants, we will now repeat our analysis for subgroups of immigrants who 1) differ in their time spent in the host country, 2) belong to different immigration cohorts, and 3) migrate at different ages. Unfortunately, our data set does not include the date of immigration to Germany. To overcome this missing information, we proxy the date of entry by the date at which immigrants are first registered as either employed or unemployed in our source data that go back until 1975. We are aware that this proxy is rather crude and disregards periods of unregistered non-employment after immigration to Germany. Recent research by Hirsch et al. (2014), however, indicated that periods of unregistered non-employment while migrating to Germany are typically rather short, that is, only slightly longer than a year on average. For this reason, we restrained ourselves from including immigrants' proxied years since migration, age at entry, and immigration cohort in the standard wage regressions presented in Table 2 , and we shall use this information in only a back-of-the-envelope manner in the following discussion.

The last row of Table 5 presents estimates of the unexplained immigrantnative wage differential for the different subgroups of immigrants (that is, the coefficients of the immigrant dummy following from running wage regressions analogous to models 2 and 3 from Table 2 for the respective subgroup). First of all, we find that immigrants who have spent at least 10 years in the German labor market experience considerably lower unexplained pay gaps relative to natives ranging from 4.6 to $5.2 \mathrm{log}$ points than those with less experience whose average gap amounts to 6.6 to $10.5 \mathrm{log}$ points. This measure is in line with the widely documented finding of partial wage assimilation over time spent in the host country (see, e.g., Dustmann and Glitz 2011). Following Chiswick (1978), the standard channel 
discussed in the literature is that during their stay in the host country immigrants acquire missing country-specific skills augmenting their productivity and being reflected in relative wage increases. From a monopsonistic perspective, gaining in country-specific skills is also likely to mitigate the search frictions faced by immigrants. Therefore, immigrants with more host-country work experience are expected to suffer less from monopsonistic discrimination. On the one hand, Table 5 makes clear that immigrants with 10 or more years of German working experience supply labor almost as elastically as natives with an insignificant implied pay gap of just $0.8 \mathrm{log}$ points. On the other hand, the supply elasticity is only 1.095 for immigrants entering the German labor market more recently, giving rise to a significant implied pay gap of $9.3 \mathrm{log}$ points, which is well in the range of the unexplained differential for this group.

In a second step, we distinguish immigrants entering the German labor market before 1990 from those arriving in later years. Following the fall of the Iron Curtain and Germany's reunification in 1990, the West German labor market saw a large inflow both of immigrants coming from Eastern European countries and of East Germans leaving the poorly performing East German labor market. Since this trend is likely to hamper immigrants' labor market perspectives and search efforts, we expect immigrants arriving in the pre-1990 period to outperform those arriving later in their wage position relative to natives and to show a larger supply elasticity reflecting their better initial position in job search. As Table 5 demonstrates, our data support both these expectations. The unexplained wage disadvantage of immigrants is 2.7 to $2.8 \mathrm{log}$ points for the pre-1990 cohort but 7.6 to $11.6 \mathrm{log}$ points for the 1990 to 2008 cohort. The earlier cohort also shows a larger supply elasticity of 1.246 compared to 1.075 for the later. As a consequence, the implied wage gap is just $2.7 \mathrm{log}$ points for immigrants arriving before 1990 but $10.1 \log$ points for immigrants arriving after, both numbers being within the respective range of estimated unexplained immigrant-native wage gaps.

Finally, we distinguish immigrants entering the German labor market aged 30 years or less from immigrants arriving at an older age. Immigrants who are older than 30 years should not only have acquired their education from the source country but also should have spent part of their employment careers outside of Germany. As a consequence, these immigrants should find it harder to move their way up the wage distribution and should to a higher degree be subject to monopsonistic discrimination. As can be seen from Table 5 , the wage disadvantage for immigrants migrating no later than at age 30 amounts to just 3.2 to $5.2 \log$ points, whereas the wage disadvantage of those migrating later in their lives is 13.1 to $16.7 \mathrm{log}$ points. In addition, immigrants moving at a younger age have a considerably higher elasticity of 1.217 leading to a predicted wage penalty of $4.7 \mathrm{log}$ points compared to those who move after turning 30 whose elasticity is estimated as 0.881 , implying a wage differential of $18.7 \log$ points. 


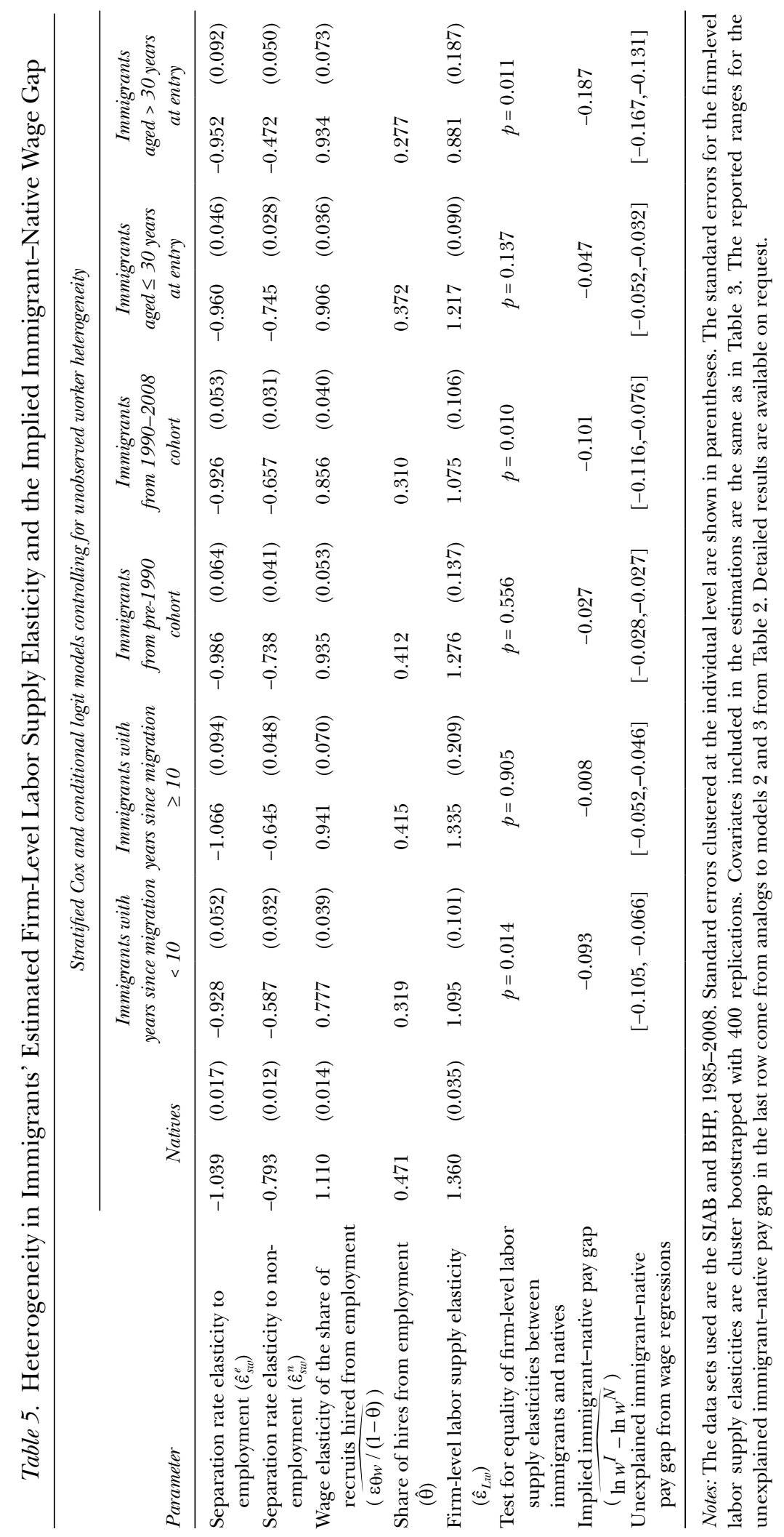


While our findings highlight the robustness of the native-immigrant difference in the elasticity of firm-level labor supply, the heterogeneity of the difference among subgroups of immigrants is also suggestive that search frictions are a likely candidate for explaining why employers possess more monopsony power over their immigrant workers. As we argued in detail above, the lower elasticity for immigrants with little work experience in Germany is likely to reflect immigrants' initial lack of country-specific skills, which narrows over the time spent in the host country. Moreover, the higher elasticity for immigrants entering the German labor market at a young age is likely to reflect their less pronounced problems in acculturating to the new environment, making them more competitive than older immigrants. Finally, the lower elasticity for immigrants arriving in the 1990 to 2008 period is likely to mirror that these immigrants entered a more crowded labor market giving rise to a worse initial position in job search. ${ }^{18}$ In addition, immigrants' job search activities seem to be further impeded by a lower degree of regional mobility. We find that the average distance between subsequent jobs is 75 kilometers for natives (or 48 minutes commuting time) but just 53 kilometers (or 36 minutes commuting time) for immigrants.

\section{Conclusions}

In this article, we have estimated the firm-level labor supply elasticity for male natives and immigrants in Germany within an estimation approach based on a dynamic monopsony model. Addressing unobserved worker heterogeneity by stratified partial likelihood and conditional logit estimators, we find that immigrants supply labor less elastically to the firm as compared to natives. Estimated supply elasticities are about 1.36 for natives but only 1.14 for immigrants. Under a simple rule of monopsonistic wage setting this elasticity differential would imply 7.7 log points lower wages for immigrants, ceteris paribus. Notably, the unexplained immigrant-native wage differential in our sample amounts to 5.8 to $8.2 \mathrm{log}$ points (depending on specification), which is very close to the differential arising under monopsonistic discrimination. Put differently, the entire observed differential would be due to monopsonistic discrimination if employers were to exploit their monopsony power over their native and immigrant workers.

When distinguishing among immigrant groups that differ in their time spent in the German labor market, their immigration cohort, and their age at entry, we find that the unexplained wage differential is larger for those groups who show a larger elasticity differential relative to natives. Immigrants with more German labor market experience, belonging to the pre1990 cohort, or entering the labor market at a younger age supply their labor more elastically at the level of the firm than those with less

\footnotetext{
${ }^{18}$ Note that our findings may also reflect drops in average cohort quality as envisaged by Borjas (1985), with later cohorts of immigrants showing a less favorable outlook in job search and thus earning lower wages.
} 
experience, migrating in the aftermath of the downfall of the Iron Curtain and Germany's reunification, or entering at an older age, respectively, and they also experience considerably lower wage penalties. Remarkably, the predicted wage gaps under monopsonistic wage setting are very close to the observed gaps for all subgroups. These findings not only strengthen the case for monopsonistic wage discrimination against immigrants but also suggest that search frictions are the likely cause of employers' more pronounced monopsony power over their immigrant workers. Moreover, they complement the extant literature that stresses the productivity effect of gains in host country-specific skills by pointing at a new channel of immigrants' partial wage assimilation.

Following Robinson (1933: 224), who argued that "just as we have price discrimination for a monopolist, so we may have price discrimination for a monopsonist," we therefore conclude that differences in firm-level labor supply elasticities between native and immigrant workers can account for a considerable part of the observed unexplained wage differential. Other than discrimination stemming from employers with a taste for discrimination, this sort of monopsonistic discrimination is profit-increasing and thus fostered by market forces in the long run. What is more, monopsonistic discrimination does not force us to introduce (arbitrary) assumptions on individuals' preferences. As Stigler and Becker (1977: 89) argued, "no significant behavior has been illuminated by assumptions of differences in tastes. Instead, they ... have been a convenient crutch to lean on when the analysis has bogged down. They give the appearance of considered judgement, yet really have only been ad hoc arguments that disguise analytical failures." For this reason, monopsonistic discrimination seems to be a more coherent theoretical framework for considering immigrant wage discrimination and offers straightforward policy implications of how to fight it. Under monopsonistic discrimination, employers discriminate against immigrant workers because doing so is profitable. On the one hand, stopping discrimination would "just" require the policymaker to remove the sources of immigrants' lower firm-level labor supply elasticity, for instance by mitigating search frictions through providing better skills on the host country's language, institutions, and labor market to immigrants. ${ }^{19}$ On the other hand, removing clichés and racism forming discriminatory employer preferences against immigrants seems to be a much harder and less obvious job.

\footnotetext{
${ }^{19}$ As pointed out by a referee, policymakers may also find it worthwhile to subsidize the mobility of immigrants, which may further erode employers' possibility to engage in monopsonistic discrimination against this group.
} 


\section{Appendix}

Table A.1. Selected Descriptive Statistics (Means)

\begin{tabular}{|c|c|c|}
\hline Variable & Natives & Immigrants \\
\hline Log daily gross wage $(€)$ & 4.442 & 4.238 \\
\hline Years since migration (years) & & 9.217 \\
\hline Years since migration $<10$ years (dummy) & & 0.619 \\
\hline Years since migration $\geq 10$ years (dummy) & & 0.381 \\
\hline Pre-1990 immigration cohort (dummy) & & 0.617 \\
\hline Immigration cohort 1990-2008 (dummy) & & 0.383 \\
\hline Age at entry (years) & & 25.806 \\
\hline Age at entry $\leq 30$ years (dummy) & & 0.734 \\
\hline Age at entry > 30 years (dummy) & & 0.266 \\
\hline Low-skilled (dummy) & 0.084 & 0.353 \\
\hline Medium-skilled (dummy) & 0.800 & 0.598 \\
\hline High-skilled (dummy) & 0.117 & 0.049 \\
\hline Age (years) & 34.431 & 35.023 \\
\hline Age 18-25 years (dummy) & 0.180 & 0.168 \\
\hline Age $26-30$ years (dummy) & 0.195 & 0.185 \\
\hline Age $31-35$ years (dummy) & 0.193 & 0.190 \\
\hline Age $36-40$ years (dummy) & 0.170 & 0.166 \\
\hline Age $41-45$ years (dummy) & 0.130 & 0.139 \\
\hline Age $46-50$ years (dummy) & 0.088 & 0.103 \\
\hline Age $51-55$ years (dummy) & 0.044 & 0.051 \\
\hline Tenure (years) & 2.649 & 2.180 \\
\hline Tenure < 1 year (dummy) & 0.526 & 0.592 \\
\hline Tenure $1-4$ years (dummy) & 0.236 & 0.213 \\
\hline Tenure 5-9 years (dummy) & 0.155 & 0.132 \\
\hline Tenure $10-14$ years (dummy) & 0.057 & 0.046 \\
\hline Tenure $15-19$ years (dummy) & 0.022 & 0.016 \\
\hline Tenure $\geq 20$ years (dummy) & 0.004 & 0.002 \\
\hline Plant size & 1043.851 & 950.498 \\
\hline Plant size $\leq 10$ (dummy) & 0.118 & 0.108 \\
\hline Plant size 11-50 (dummy) & 0.263 & 0.250 \\
\hline Plant size 51-200 (dummy) & 0.258 & 0.284 \\
\hline Plant size 201-1,000 (dummy) & 0.222 & 0.227 \\
\hline Plant size $>1,000$ (dummy) & 0.139 & 0.131 \\
\hline Share of immigrant workers in workforce & 0.079 & 0.208 \\
\hline Share of female workers in workforce & 0.278 & 0.246 \\
\hline Share of high-skilled workers in workforce & 0.078 & 0.054 \\
\hline Share of low-skilled workers in workforce & 0.209 & 0.316 \\
\hline Share of part-time workers in workforce & 0.115 & 0.100 \\
\hline Median age of workers at the plant & 37.299 & 37.065 \\
\hline Regional unemployment rate & 8.656 & 8.378 \\
\hline Observations & $2,462,340$ & 465,940 \\
\hline
\end{tabular}

Notes: The data sets used are the SIAB and BHP, 1985-2008. 


\section{Table A.2. Estimated Firm-Level Labor Supply Elasticities When Excluding High- Skilled Workers or Restricting to Workers in Low-Skilled Occupations}

\begin{tabular}{|c|c|c|c|c|c|c|c|}
\hline \multirow{3}{*}{$\begin{array}{l}\text { Parameter } \\
\text { Separation rate elasticity to } \\
\quad \text { employment }\left(\hat{\varepsilon}_{s w}^{e}\right)\end{array}$} & \multicolumn{4}{|c|}{$\begin{array}{c}\text { Stratified Cox and conditional logit } \\
\text { models when excluding high-skilled } \\
\text { workers }\end{array}$} & \multicolumn{3}{|c|}{$\begin{array}{c}\text { Stratified Cox and conditional logit } \\
\text { models when restricting to workers in } \\
\text { low-skilled occupations }\end{array}$} \\
\hline & \multicolumn{2}{|c|}{ Natives } & \multicolumn{2}{|c|}{ Immigrants } & \multicolumn{2}{|c|}{ Natives } & Immigrants \\
\hline & -1.101 & $(0.018)$ & -1.002 & $(0.042)$ & -1.114 & $(0.028)$ & $-1.103(0.055)$ \\
\hline $\begin{array}{l}\text { Separation rate elasticity to } \\
\text { non-employment }\left(\hat{\varepsilon}_{s w}^{n}\right)\end{array}$ & -0.792 & $(0.013)$ & -0.685 & $(0.025)$ & -0.791 & $(0.019)$ & $-0.728 \quad(0.032)$ \\
\hline $\begin{array}{l}\text { Wage elasticity of the share of } \\
\text { recruits hired from } \\
\text { employment }(\varepsilon \theta w /(1-\theta))\end{array}$ & 0.994 & $(0.015)$ & 0.874 & $(0.033)$ & 0.780 & $(0.021)$ & $0.822(0.040)$ \\
\hline $\begin{array}{l}\text { Share of hires from } \\
\text { employment }(\hat{\theta})\end{array}$ & 0.461 & & 0.343 & & 0.427 & & 0.337 \\
\hline $\begin{array}{l}\text { Firm-level labor supply } \\
\text { elasticity }\left(\hat{\varepsilon}_{L w}\right)\end{array}$ & 1.500 & $(0.038)$ & 1.221 & $(0.081)$ & 1.637 & $(0.056)$ & $1.408(0.120)$ \\
\hline $\begin{array}{l}\text { Test for equality of firm-level } \\
\text { labor supply elasticities } \\
\text { between immigrants and } \\
\text { natives }\end{array}$ & \multicolumn{4}{|c|}{$p=0.002$} & \multicolumn{3}{|c|}{$p=0.075$} \\
\hline $\begin{array}{l}\text { Implied immigrant-native pay } \\
\quad \operatorname{gap}\left(\frac{\ln w^{I}-\ln w^{N}}{)}\right.\end{array}$ & \multicolumn{4}{|c|}{-0.084} & \multicolumn{3}{|c|}{-0.058} \\
\hline
\end{tabular}

Notes: The data sets used are the SIAB and BHP, 1985-2008. Standard errors clustered at the individual level are shown in parentheses. The standard errors for the firm-level labor supply elasticities are cluster bootstrapped with 400 replications. Covariates included in the estimations are the same as in Table 3 . Detailed results are available on request. 


\section{Table A.3. Estimated Firm-Level Labor Supply Elasticities When Not Controlling for Unobserved Heterogeneity or Not Distinguishing Employment and Non- Employment as Distinct Labor Market States}

\begin{tabular}{|c|c|c|c|c|c|c|c|c|}
\hline \multirow{3}{*}{$\begin{array}{l}\text { Parameter } \\
\text { Separation rate elasticity to } \\
\quad \text { employment }\left(\hat{\varepsilon}_{s w}^{e}\right)\end{array}$} & \multicolumn{4}{|c|}{$\begin{array}{c}\text { Cox and logit models not } \\
\text { controlling for unobserved worker } \\
\text { heterogeneity }\end{array}$} & \multicolumn{4}{|c|}{$\begin{array}{c}\text { Stratified Cox models lumping } \\
\text { together all separations and using } \\
\text { Equation (4) }\end{array}$} \\
\hline & \multicolumn{2}{|c|}{ Natives } & \multicolumn{2}{|c|}{ Immigrants } & \multicolumn{2}{|c|}{ Natives } & \multicolumn{2}{|c|}{ Immigrants } \\
\hline & -0.970 & $(0.009)$ & -1.096 & $(0.021)$ & & & & \\
\hline $\begin{array}{l}\text { Separation rate elasticity to } \\
\text { non-employment }\left(\hat{\varepsilon}_{s w}^{n}\right)\end{array}$ & -1.286 & $(0.007)$ & -1.112 & $(0.014)$ & & & & \\
\hline $\begin{array}{l}\text { Wage elasticity of the share of } \\
\text { recruits hired from } \\
\text { employment }(\varepsilon \theta w /(1-\theta))\end{array}$ & 1.309 & $(0.010)$ & 0.932 & $(0.022)$ & & & & \\
\hline $\begin{array}{l}\text { Share of hires from } \\
\text { employment }(\hat{\theta})\end{array}$ & 0.471 & & 0.346 & & & & & \\
\hline $\begin{array}{l}\text { Firm-level labor supply } \\
\text { elasticity }\left(\hat{\varepsilon}_{L w}\right)\end{array}$ & 1.415 & $(0.021)$ & 1.593 & $(0.045)$ & 1.836 & $(0.024)$ & 1.683 & $(0.053)$ \\
\hline $\begin{array}{l}\text { Test for equality of firm-level } \\
\text { labor supply elasticities } \\
\text { between immigrants and } \\
\text { natives }\end{array}$ & \multicolumn{4}{|c|}{$p<0.001$} & \multicolumn{4}{|c|}{$p=0.008$} \\
\hline $\begin{array}{l}\text { Implied immigrant-native pay } \\
\quad \operatorname{gap}\left(\frac{\ln w^{I}-\ln w^{N}}{)}\right)\end{array}$ & \multicolumn{4}{|c|}{0.048} & \multicolumn{4}{|c|}{-0.031} \\
\hline
\end{tabular}

Notes: The data sets used are the SIAB and BHP, 1985-2008. Standard errors clustered at the individual level are shown in parentheses. The standard errors for the firm-level labor supply elasticities are cluster bootstrapped with 400 replications. Covariates included in the estimations are the same as in Table 3. Detailed results are available on request. 
Table A.4. Estimated Firm-Level Labor Supply Elasticities When Not Controlling for Occupations or Plant Characteristics

\begin{tabular}{|c|c|c|c|c|c|c|c|c|}
\hline \multirow{3}{*}{$\begin{array}{l}\text { Parameter } \\
\text { Separation rate elasticity to } \\
\text { employment }\left(\hat{\varepsilon}_{s w}^{e}\right)\end{array}$} & \multicolumn{4}{|c|}{$\begin{array}{l}\text { Stratified Cox and conditional logit } \\
\text { models without occupation controls }\end{array}$} & \multicolumn{4}{|c|}{$\begin{array}{l}\text { Stratified Cox and conditional logit } \\
\text { models without plant controls }\end{array}$} \\
\hline & \multicolumn{2}{|c|}{ Natives } & \multicolumn{2}{|c|}{ Immigrants } & \multicolumn{2}{|c|}{ Natives } & \multicolumn{2}{|c|}{ Immigrants } \\
\hline & -1.050 & $(0.017)$ & -0.970 & $(0.041)$ & -1.175 & $(0.016)$ & -1.238 & $(0.038)$ \\
\hline $\begin{array}{l}\text { Separation rate elasticity to non- } \\
\text { employment }\left(\hat{\varepsilon}_{s w}^{n}\right)\end{array}$ & -0.820 & $(0.012)$ & -0.699 & $(0.024)$ & -0.846 & $(0.011)$ & -0.768 & $(0.022)$ \\
\hline $\begin{array}{l}\text { Wage elasticity of the share of } \\
\text { recruits hired from } \\
\text { employment }(\varepsilon \theta w /(1-\theta))\end{array}$ & 1.124 & $(0.014)$ & 0.923 & $(0.032)$ & 1.158 & $(0.014)$ & 1.088 & $(0.030)$ \\
\hline $\begin{array}{l}\text { Share of hires from employment } \\
\quad(\hat{\theta})\end{array}$ & 0.471 & & 0.346 & & 0.471 & & 0.346 & \\
\hline $\begin{array}{l}\text { Firm-level labor supply elasticity } \\
\qquad\left(\hat{\varepsilon}_{L w}\right)\end{array}$ & 1.384 & $(0.034)$ & 1.158 & $(0.083)$ & 1.563 & $(0.034)$ & 1.456 & $(0.079)$ \\
\hline $\begin{array}{l}\text { Test for equality of firm-level } \\
\text { labor supply elasticities } \\
\text { between immigrants and } \\
\text { natives }\end{array}$ & \multicolumn{4}{|c|}{$p=0.014$} & \multicolumn{4}{|c|}{$p=0.225$} \\
\hline $\begin{array}{l}\text { Implied immigrant-native pay } \\
\quad \operatorname{gap}\left(\frac{\ln w^{I}-\ln w^{N}}{)}\right)\end{array}$ & \multicolumn{4}{|c|}{-0.076} & \multicolumn{4}{|c|}{-0.028} \\
\hline
\end{tabular}

Notes: The data sets used are the SIAB and BHP, 1985-2008. Standard errors clustered at the individual level are shown in parentheses. The standard errors for the firm-level labor supply elasticities are cluster bootstrapped with 200 replications. Covariates included in the estimations are the same as in Table 3. Detailed results are available on request.

\section{References}

Algan, Yann, Christian Dustmann, Albrecht Glitz, and Alan Manning. 2010. The economic situation of first and second-generation immigrants in France, Germany and the United Kingdom. Economic Journal 120(542): F4-F30.

Altonji, Joseph G., and Nicolas Williams. 2005. Do wages rise with job seniority? A reassessment. Industrial and Labor Relations Review 58(3): 370-97.

Angrist, Joshua D., and Jörn-Steffen Pischke. 2009. Mostly Harmless Econometrics: An Empiricist's Companion. Princeton, NJ: Princeton University Press.

Ashenfelter, Orley C., Henry Farber, and Michael R. Ransom. 2010. Labor market monopsony. Journal of Labor Economics 28 (2): 203-10.

Åslund, Olof, and Oskar Nordström Skans. 2010. Will I see you at work? Ethnic workplace segregation in Sweden, 1985-2002. Industrial and Labor Relations Review 63(3): 471-93.

Bartelheimer, Peter, and Markus Wieck. 2005. Arbeitslosigkeit und Unterbeschäftigung. In Soziologisches Forschungsinstitut, Institut für Arbeitsmarkt- und Berufsforschung, Institut für Sozialwissenschaftliche Forschung, and Internationales Institut für empirische Sozialökonomie (Eds.), Berichterstattung zur sozioökonomischen Entwicklung in Deutschland Arbeit und Lebensweisen. Erster Bericht, pp. 271-302. Wiesbaden: VS Verlag für Sozialwissenschaften.

Barth, Erling, Bernt Bratsberg, and Oddbjørn Raaum. 2012. Immigrant wage profiles within and between establishments. Labour Economics 19(4): 541-56.

Barth, Erling, and Harald Dale-Olsen. 2009. Monopsonistic discrimination, worker turnover, and the gender wage gap. Labour Economics 16(5): 589-97.

Becker, Garry S. 1971. The Economics of Discrimination, 2nd ed. Chicago, IL: Chicago University Press. 
Bhaskar, Venkataraman, and Ted To. 1999. Minimum wages for Ronald McDonald monopsonies: A theory of monopsonistic competition. Economic Journal 109(455): 190-203.

Booth, Alison L., and Melvyn G. Coles. 2007. A microfoundation for increasing returns in human capital accumulation and the under-participation trap. European Economic Review 51(7): 1661-81.

Booth, Alison L., and Pamela Katic. 2011. Estimating the wage elasticity of labour supply to a firm: What evidence is there for monopsony? Economic Record 87 (278): 359-69.

Borjas, George J. 1985. Assimilation, changes in cohort quality, and the earnings of immigrants. Journal of Labor Economics 3(4): 463-89.

Brücker, Herbert, and Elke J. Jahn. 2011. Migration and wage-setting: Reassessing the labor market effects of migration. Scandinavian Journal of Economics 113(2): 286-317.

Brueckner, Jan K., Jacques-François Thisse, and Yves Zenou. 2002. Local labor markets, job matching, and urban location. International Economic Review 43(1): 155-71.

Burdett, Kenneth, and Dale T. Mortensen. 1998. Wage differentials, employer size, and unemployment. International Economic Review 39(2): 257-73.

Büttner, Thomas, and Susanne Rässler. 2008. Multiple imputation of right-censored wages in the German IAB Employment Sample considering heteroscedasticity. IAB Discussion Paper No. 44/2008. Nuremberg: Institute for Employment Research.

Cameron, A. Colin, and Pravin K. Trivedi. 2005. Microeconometrics: Methods and Applications. Cambridge: Cambridge University Press.

Card, David E., and Alan B. Krueger. 1995. Myth and Measurement: The New Economics of the Minimum Wage. Princeton, NJ: Princeton University Press.

Chiswick, Barry R. 1978. The effect of Americanization on the earnings of foreign-born men. Journal of Political Economy 86(5): 81-87.

Chiswick, Barry R., Yew Liang Lee, and Paul W. Miller. 2005. A longitudinal analysis of immigrant occupational mobility: A test of the immigrant assimilation hypothesis. International Migration Review 39(2): 332-53.

Constant, Amelie, and Douglas S. Massey. 2005. Labor market segmentation and the earnings of German guestworkers. Population Research and Policy Review 24(5): 489-512.

Cutler, David M., Edward L. Glaeser, and Jacob L. Vigdor. 2008. When are ghettos bad? Lessons from immigrant segregation in the United States. Journal of Urban Economics 63(3): 759-74.

Depew, Briggs, Peter Norlander, and Todd A. Sørensen. 2013. Flight of the H-1B: Inter-firm mobility and return migration patterns for skilled guest workers. IZA Discussion Paper No. 7456. Bonn: Institute for the Study of Labor.

Depew, Briggs, and Todd A. Sørensen. 2013. The elasticity of labor supply to the firm over the business cycle. Labour Economics 24(1): 196-204.

Dorner, Matthias, Jörg Heining, Peter Jacobebbinghaus, and Stefan Seth. 2010. The sample of integrated labour market biographies. Schmollers Jahrbuch 130(4): 599-608.

Dustmann, Christian, and Albrecht Glitz. 2011. Migration and education. In Eric A. Hanushek, Stephen Machin, and Ludger Wößmann (Eds.). Handbook of the Economics of Education, Vol. IV, pp. 327-439. Amsterdam: Elsevier.

Dustmann, Christian, Albrecht Glitz, and Thorsten Vogel. 2010. Employment, wages, and the economic cycle: Differences between immigrants and natives. European Economic Review 54(1): 1-17.

Eckstein, Zvi, and Yoram Weiss. 2004. On the wage growth of immigrants: Israel, 1990-2000. Journal of the European Economic Association 2(4): 665-95.

Elliot, Robert J. R., and Joanne K. Lindley. 2008. Immigrant wage differentials, ethnicity and occupational segregation. Journal of the Royal Statistical Society (Series A) 171(3): 645-71.

Falch, Torberg. 2010. The elasticity of labor supply at the establishment level. Journal of Labor Economics 28(2): 237-66.

- 2011. Teacher mobility responses to wage changes: Evidence from a quasi-natural experiment. American Economic Review (Papers and Proceedings) 101 (3): 460-65.

Fitzenberger, Bernd, Aderonke Osikominu, and Robert Völter. 2006. Imputation rules to improve the education variable in the IAB Employment Subsample. Schmollers Jahrbuch 126(3): 405-36. 
Glitz, Albrecht. 2012. The labor market impact of immigration: A quasi-experiment exploiting immigrant location rules in Germany. Journal of Labor Economics 30(1): 175-213.

. 2014. Ethnic segregation in Germany. Labour Economics 29(1): 28-40.

Granato, Nadia. 2009. Regional concentration and labour market success: Endogenous and exogenous effects of relative minority group size. Kölner Zeitschrift für Soziologie und Sozialpsychologie 61 (3): 387-409.

Hirsch, Boris, Elke J. Jahn, Ott Toomet, and Daniela Hochfellner. 2014. Do better pre-migration skills accelerate immigrants' wage assimilation? Labour Economics 30(1): 212-22.

Hirsch, Boris, Thorsten Schank, and Claus Schnabel. 2010. Differences in labor supply to monopsonistic firms and the gender pay gap: An empirical analysis using linked employer-employee data from Germany. Journal of Labor Economics 28 (2): 291-330.

Hotchkiss, Julie L., and Myriam Quispe-Agnoli. 2012. Employer monopsony power in the labor market for undocumented workers. Working Paper No. 2009-14d. Atlanta, GA: Federal Reserve Bank of Atlanta.

Kalbfleisch, John D., and Ross L. Prentice. 2002. The Statistical Analysis of Failure Time Data, 2nd ed. Hoboken, NJ: John Wiley \& Sons.

Kee, Peter. 1995. Native-immigrant wage differentials in the Netherlands: Discrimination? Oxford Economic Papers 47(2): 302-17.

Lehmer, Florian, and Johannes Ludsteck. 2011. The immigrant wage gap in Germany: Are East Europeans worse off? International Migration Review 45 (4): 872-906.

Manning, Alan. 2003a. Monopsony in Motion: Imperfect Competition in Labor Markets. Princeton, NJ: Princeton University Press.

. 2003b. The real thin theory: Monopsony in modern labour markets. Labour Economics 10(2): 105-31.

- 2011. Imperfect competition in the labor market. In Orley C. Ashenfelter and David E. Card (Eds.), Handbook of Labor Economics, Vol. 4B, pp. 973-1041. Amsterdam: Elsevier.

Matsudaira, Jordan D. 2014. Monopsony in the low-wage labor market? Evidence from minimum nurse staffing regulations. Review of Economics and Statistics 96(1): 92-102.

Nielsen, Helena Skyt, Michael Rosholm, Nina Smith, and Leif Husted. 2004. Qualifications, discrimination, or assimilation? An extended framework for analysing immigrant wage gaps. Empirical Economics 29(4): 855-83.

Pencavel, John H. 1972. Wages, specific training, and labor turnover in U.S. manufacturing industries. International Economic Review 13(1): 53-64.

Pendakur, Krishna, and Simon D. Woodcock. 2010. Glass ceilings or glass doors? Wage disparity within and between firms. Journal of Business and Economic Statistics 28(1): 181-89.

Ransom, Michael, and Ronald L. Oaxaca. 2010. New market power models and sex differences in pay. Journal of Labor Economics 28(2): 267-89.

Ransom, Michael, and David P. Sims. 2010. Estimating the firm's labor supply curve in a "new monopsony" framework: Schoolteachers in Missouri. Journal of Labor Economics 28(2): 331-55.

Ridder, Geert, and İnsan Tunali. 1999. Stratified partial likelihood estimation. Journal of Econometrics 92(2): 193-232.

Robinson, Joan V. 1933. The Economics of Imperfect Competition. London: MacMillan.

Spengler, Anja. 2008. The establishment history panel. Schmollers Jahrbuch 128(3): 501-9.

Staiger, Douglas O., Joanne Spetz, and Ciaran S. Phibbs. 2010. Is there monopsony power in the labor market? Evidence from a natural experiment. Journal of Labor Economics 28(2): 211-36.

Statistisches Bundesamt. 2012. Bevölkerung mit Migationshintergrund - Ergebnisse des Mikrozensus - Fachserie 1, Reihe 2.2, 2011. Wiesbaden: Statistisches Bundesamt.

Stigler, George J., and Gary S. Becker. 1977. De gustibus non est disputandum. American Economic Review 67 (2): 76-90.

Webber, Douglas A. 2013a. Firm market power and the earnings distribution. IZA Discussion Paper No. 7342. Bonn: Institute for the Study of Labor.

- 2013b. Firm-level monopsony and the gender pay gap. IZA Discussion Paper No. 7343. Bonn: Institute for the Study of Labor.

Zwick, Thomas. 2011. Seniority wages and establishment characteristics. Labour Economics 18(6): 853-61.

. 2012. Consequences of seniority wages on the employment structure. Industrial and Labor Relations Review 65(1): 108-25. 